DIVERSITY OF THE KNOWN LIGANDS FOR CLONED G PROTEIN-COUPLED RECEPTORS

\begin{tabular}{|c|c|}
\hline Biogenic amines & $\begin{array}{l}\text { Epinephrine } \\
\text { Norepinephrine } \\
\text { Dopamine } \\
\text { Acetylcholine } \\
\text { Histamine } \\
\text { 5-Hydroxytryptamine } \\
\text { Adenosine }\end{array}$ \\
\hline Tachykinins & $\begin{array}{l}\text { Substance P } \\
\text { Substance K } \\
\text { Neuromedin K }\end{array}$ \\
\hline Glycoprotein hormones & $\begin{array}{l}\text { Thyrotropin } \\
\text { Follicle-stimulating } \\
\text { hormone } \\
\text { Lutropin/ } \\
\text { choriogonadotropin }\end{array}$ \\
\hline $\begin{array}{l}\text { Polypeptide hormones } \\
\text { Brain/gut peptide } \\
\text { hormones }\end{array}$ & $\begin{array}{l}\text { Parathyroid hormone } \\
\text { Angiotensin } \\
\text { Arginine-vasopressin } \\
\text { Vasoactive intestinal } \\
\text { polypeptide } \\
\text { Bombesin/gastrin- } \\
\text { releasing hormone } \\
\text { Thyrotropin-releasing } \\
\text { hormone }\end{array}$ \\
\hline $\begin{array}{l}\text { Arachidonic acid } \\
\text { derivatives }\end{array}$ & Thromboxane $\mathrm{A}_{2}$ \\
\hline Sensory stimuli & $\begin{array}{l}\text { Light (i.e. retinal) } \\
\text { Odorants }\end{array}$ \\
\hline Miscellaneous & $\begin{array}{l}\text { Thrombin } \\
\text { Endothelins } \\
\text { Platelet-activating factor } \\
N \text {-formyl peptide } \\
\text { Mating factors (yeast) } \\
\text { cAMP (Dictyostelium) } \\
\text { Cannabinoids } \\
\mathrm{C}_{5 \mathrm{~A}}\end{array}$ \\
\hline
\end{tabular}

phosphorylation; and conserved sites for several other post-translational modifications, such as fatty acylation and disulphide bond formation (see figure). Despite the extraordinary diversity of ligands for these receptors (see table), these structural features have been found in most instances. The cloning $^{9}$ of what seems to be a large superfamily of seven-transmembrane-domain receptors for odorants, which possess all of these features, greatly expands the size of the family. (Doron Lancet discussed these putative odorant receptors in detail in his News and Views article that appeared in last week's issue ${ }^{10}$.)

That seemingly minor variations on this structural arrangement have worked so well over millions of years of evolutionary time implies that the 'ground plan' represents a particularly efficient way to accomplish the job of transmitting an extracellular signal to the inner metabolic machinery of a cell. Nonetheless, our understanding of just how it works is still rudimentary. Ligands may interact with a 'pocket' created by some number of the (presumably) $\alpha$-helical membrane-spanning regions, while other regions on the inner surface of the receptor interact with and activate specific $G$ protein(s), thus determining the nature of the biological response ${ }^{3}$.

Even though the main structural and topographical features of the receptors with seven transmembrane segments have been highly conserved, several variations have been superimposed upon them to meet the demands of interacting with structurally diverse ligands. In the case of small amine ligands, such as catecholamines, acetylcholine, histamine or serotonin, the membrane-spanning helices seem to form a pocket into which the ligand 'fits'. The same is probably true for the receptors for small peptides such as angiotensin and the tachykinins.

With the receptors for the big heterodimeric glycoprotein hormones, such as luteinizing hormone, thyroid-stimulating hormone and follicle-stimulating hormone, a large (over 300 amino-acid) $\mathrm{N}$-terminal extracellular domain is present. This sugarrich region contains the principal determinants for binding the hormones, and it may serve to position the large ligand to interact secondarily with the membrane-spanning regions. In the case of rhodopsin, a very specialized situation has evolved where the small chromophore retinal is covalently attached to the seventh transmembranespanning domain. Retinal nestles in a pocket created by the $\alpha$-helices within the membrane and undergoes conformational changes when it absorbs a photon of light. In this instance, the light-modified retinal moiety in effect represents the 'ligand'.

Vu et al. describe a further highly unusual specialization of receptor structure in which the 'ligand' actually resides within the $\mathrm{N}$ terminus of the receptor molecule, and is only unmasked by a proteolytic clip mediated by thrombin. Interestingly, the site at which thrombin presumably cleaves the receptor is similar in sequence to that cleaved by thrombin in the zymogen protein $\mathrm{C}$ (LPDR/S or I, in the single-letter aminoacid code).

The biological effects of thrombin are not limited to aggregation of platelets, but probably include a variety of responses to vascular injury such as chemotaxis of monocytes, mitogenesis of lymphocytes and stimulation of production of platelet-derived growth factor by endothelial cells. It remains to be seen whether all of these responses are mediated by the same thrombin receptor, or whether a subfamily of such receptors exists (and, if so, whether they share the same activation mechanism). Beyond this is the fascinating issue of how many more variations on the theme of the seven-transmembrane-domain receptor remain to be discovered.

Robert J. Lefkowitz is in the Howard Hughes Medical Institute Research Laboratories, Duke University Medical Center, Post Box 3821, Durham, North Carolina 27710, USA.

1. Vu, T. K. H., Hung, D. T., Wheaton, V. I. \& Coughlin, S. R. Ce/l 64, 1057-1068 (1991).

2. Gilman, A. G. A. Rev. Biochem. 56, 615-649 (1987).

3. DohIman, H. D., Thorner, J., Caron, M. G. \& Lefkowitz, R. J. A. Rev. Biochem. 60, 653-688 (1991).

4. Ovchinnikov, Y. A. FEBS Lett. 148, 179-191 (1982).

5. Nathans, J. \& Hogness, D. S. Proc. natn. Acad. Sci. U.S.A. 81, 4851-4855 (1984)

6. Applebury. M. L. \& Hargrave, P. A. Vision Res. 26 , $1881-1895$ (1987).

Henderson, R. et al. J. molec. Biol. 213, 899-929 (1990)

8. Dixon, R.A.F. et al. Nature 321, 75-79 (1986).

. Buck, L. \& Axel, R. Cel/ 65, 175-187 (1991)

10. Lancet. D. Nature 351, 275-276 (1991)

\section{Safety in numbers}

LAST week Daedalus was reflecting on the 'sperm-competition' which may go on in the reproductive tract of a woman with many recent lovers. He decided that sperm from different males must compete to fertilize the ovum by direct aggression - like fleets of rival battleships. He set DREADCO's biochemists to look for forms of chemical warfare between the sperm: toxins, anti-toxin defences, and so on.

He now muses that the battle may be more like a jamming contest between enemy radio transmitters. Sperm in the female reproductive tract do not wander vaguely around hoping to encounter an ovum somewhere. They swim purposefully towards it as soon as it appears. They seem attracted by a chemotactic effluvium of some kind. One obvious way for sperm to sabotage their rivals is to confuse them with false chemical signals.

This powerful form of competition has one serious problem. A jamming battle may simply have no winners. All parties may be utterly confounded by the mass of fake signals. A woman with sufficient lovers might thus escape pregnancy altogether. This, says Daedalus, may explain how prostitutes and courtesans managed in the days before reliable contraception. Les grandes horizontales relied on their many lovers to cancel each other out. In their scrutiny of sperm-battles under the microscope, DREADCO's biochemists are looking out for such 'suicide pact' effects. If they find them, a new and powerful spermjamming contraceptive may be possible.

But their real goal is subtler still. When the outcomes of sufficient sperm-battles are known, and their chemical weapons toxins or false chemotactic emissions are identified, it should be possible to divide sperm into specific classes, each vulnerable or invulnerable to known chemical weapons. Spermicides based on these substances will incapacitate the sperm of some men, but not those of others. They will form the basis of DREADCO's new range of selective spermicides.

These wonderful products will give women full control of their maternal ambitions. Some will be broad-brush formulations, child-proofing the user against whole classes of dishy undesirables, while leaving her open to more well-advised reproductive offers. Some will be more exactly targeted, and these will be individually compounded in DREADCO's Selective Fertility Clinic. One client may wish to be safely infertile towards her lover while reproductively open to her husband (or vice versa); another may wish to bear just one man's child from a galaxy of active admirers. The clinic will do its best to oblige. Clients may need to deploy a certain seductive cunning to obtain the relevant semen samples for analysis. David Jones 